\title{
Endophytic fungal assemblages of Zanthoxylum oxyphyllum Edgew. and their antimicrobial potential
}

\author{
Rajreepa Talukdar \& Kumananda Tayung* \\ Department of Botany, Gauhati University, Guwahati 781 014, India \\ *Email: kumanand@gauhati.ac.in
}

\section{ARTICLE HISTORY}

Received: 10 October 2020

Accepted: 18 December 2020

Published: 01 January 2021

\section{KEYWORDS}

Medicinal plant

Endophytic fungi

Antimicrobial activity

Colletotrichum

Fusarium

\section{ABSTRACT}

Zanthoxylum oxyphyllum Edgew. is a medicinal plant widely been used by the local tribal communities of Assam as an alternative source of medicine for the treatment of various diseases. In the present study, endophytic fungi associated with Z. oxyphyllum were undertaken with an aim to investigate the isolates for their antimicrobial potential. The endophytic fungi were recovered using four different media, namely, Malt Extract Agar (MEA) media, Potato Dextrose Agar (PDA) media, Water Agar (WA) media and media amended with the Plant Extract (PEA) from samples collected from three sites. Altogether, 18 isolates of endophytic fungi were isolated from 150 surface sterilized and healthy leaf fragments. Colletotrichum was found to be dominant endophytic genus with 7 different species. Other isolated endophytic fungal genera were Fusarium, Curvularia, Aspergillus, Corynespora and isolates belonging non-sporulating fungi categorised as Mycelia Sterilia. The endophytic fungi were determined for antimicrobial activity against selected clinically significant human pathogenic test organisms. Ethyl acetate crude extracts of all endophytic fungi exhibited antimicrobial activity by inhibiting a minimum of one of the four test pathogens. Amongst the isolates, crude extracts obtained from Fusarium sp. and five Colletotrichum spp. showed wide-spectrum antimicrobial activity against all the test organisms. The study indicated that Z. oxyphyllum harbours a wide range of endophytes capable of producing secondary metabolites with antimicrobial properties. Further detailed investigation of their bioactive metabolites might lead to discovery of compounds with potential therapeutic applications as a new source of medicine.

\section{Introduction}

Plants known to possess medicinal values have been used in traditional folk medicine by ethnic tribal communities all over the world including India. They are also potential sources of drugs since long back and recently used for the development of modern and commercial medicines. Currently, medicinal plants used in the commercial drug industry have been overexploited for the production of plant-derived drugs. This has led to an increase in the amount of plant biomass needed for the production of even a small quantity of potentially active commercial drugs. Additionally, there are increased reports of resistance developed by most of the pathogenic microorganisms against already available commercial drugs (1). This has become a serious concern for the health services around the world. Therefore, a thorough search for new and effective antimicrobial agents is indispensable and this can only be done by exploring new niches and habitats $(2,3)$. Plants all over the globe are reported to harbor a wide range of non-pathogenic microflora within their tissues which are known as endophytes (4). Endophytic microorganisms, especially fungi inhabiting medicinal plants have the ability of synthesizing bioactive secondary metabolites analogous to those produced by their respective host plants (5). These microorganisms are prominent producers of bioactive secondary metabolites like terpenoids, lactones, steroids, quinones, alkaloids, isocoumarins, phenyl propanoids and phenols (6). Plants growing in regions with high biodiversity having medicinal properties and used in traditional medicine has been reported to be a significant area for exploration of new bioactive strains of endophytic

(c) Talukdar \& Tayung (2021). This is an open-access article distributed under the terms of the Creative Commons Attribution License, which permits unrestricted use, distribution and reproduction in any medium, provided the original author and source are credited (https://creativecommons.org/licenses/by/4.0/).

To cite this article: Talukdar R, Tayung K. Endophytic fungal assemblages of Zanthoxylum oxyphyllum and their antimicrobial potential. Plant Science Today. 2021;8(1):132-139. https://doi.org/10.14719/pst.2021.8.1.979 
fungi. Researchers were of the opinion that areas with high biodiversity as well as high numbers of endemic plant species might be the most possible niches for endophytes with novel chemistry (7). Another prospect also suggests that the valuable medicinal qualities of such plants might be a consequence of the metabolites produced by their endophytic microflora (8).

Zanthoxylum oxyphyllum Edgew. belonging to the family Rutaceae is a spiny shrub that sometimes adapts to climbing habit. It is commonly known as Prickly ash and by various other local names in Assam like Mezenga or Mejenga (Assamese) and Onger (by Mising tribe of Assam). The plant has been used as traditional medicine by the ethnic communities of the North East India, especially by the tribal population of Assam. Tender shoots and leaves of this plant are taken as vegetable and also in non-vegetarian dishes. They have been found to aid against stomach disorder, act as a blood purifier as well as against leucoderma (9). Fruits of $Z$. oxyphyllum are used as spice and are known to help in digestive disorders. The bark of the plant is commonly applied to treat skin diseases, rheumatism, ulcers, varicose veins, leg aches, inflammations, fever and hypotension. In addition to this, it also has stimulant, astringent and digestive properties and is used for the treatment of dyspepsia and diarrhoea (10). Studies show that endophytic fungi inhabiting medicinal plants synthesize natural compounds that possess an inhibitory effect against pathogenic microorganisms as well as cure various diseases (11). The typical example is that of the first compound "taxol", an anticancer agent that is produced by Taxus brevifolia and its associated endophyte, Taxomyces andreanae (12). The isolation and identification of endophytic mycobiotaarethus necessary to have an insight to their bioactive potential. However, there are no reports on the endophytic fungi of this plant species in spite of their wide medicinal uses. $Z$. oxyphyllum is one such plant which is widely used by the ethnic tribal communities of Assam for the treatment of various ailments. Therefore, the present study was directed to isolate and identify endophytic fungi associated with healthy leaf tissues of $Z$. oxyphyllum with an aim to screen the isolates for antimicrobial activities against some selected clinically significant human test pathogens so that potent isolate could be studied further to discover potential antimicrobial agents.

\section{Materials and Methods}

\section{Sample collection}

Healthy plant samples of Zanthoxylum oxyphyllum were collected from three different locations of Assam, such as Jonai $\left(27.8323^{\circ} \mathrm{N}, 95.2214^{\circ} \mathrm{E}\right)$, Boko $\left(25.9778^{\circ} \mathrm{N}, 91.2356^{\circ} \mathrm{E}\right)$ and Goalpara $\left(26.1641^{\circ} \mathrm{N}\right.$, $\left.90.6252^{\circ} \mathrm{E}\right)$. Leaves of five individual plants from each site were randomly selected and collected in sterile polyethene bags. The collected plant specimen was identified by referring herbaria and authenticated by Dr. Souravjyoti Borah (Taxonomist). A voucher specimen is being deposited in the Gauhati University Herbarium, Department of Botany (GUBH) with an accession number 18767. Plant samples were then brought to the laboratory for the isolation of endophytic fungi.

\section{Isolation of endophytic fungi}

Since there are no earlier reports of isolation of endophytic fungi from Zanthoxylum oxyphyllum, healthy leaf tissues were surface sterilized by developing a standard protocol. Leaves were sequentially dipped in $70 \%$ ethanol $(2 \mathrm{~min})$, followed by $0.5 \%$ sodium hypochlorite $(1 \mathrm{~min})$ and then rinsed twice with sterile distilled water (1 min each time). Leaves were then allowed to surface dry under a Laminar Air Flow Chamber. Small circular fragments of leaves measuring $0.5 \mathrm{~mm}$ in diameter were punched out with the help of a sterile puncture. These sterilized leaf fragments were then placed in four different mycological media namely, Potato Dextrose Agar (PDA), Malt Extract Agar (MEA), Water Agar (WA) media and also media amended with the Plant Extract (PEA) that were supplemented with streptomycin sulphate $(50 \mu \mathrm{g} / \mathrm{ml})$ and incubated at $25 \pm 2^{\circ} \mathrm{C}$ for about 2 weeks. The effectiveness of surface sterilization process was verified according to the standard method of rubbing a surface sterilized leaf on a sterile PDA plate (13). Fragments plated were observed daily for the growth of endophytic fungi. Fungal hyphae found growing from the surfaced sterilized leaf fragments were immediately transferred onto PDA slants and stored at $4{ }^{\circ} \mathrm{C}$ for further study. Absence of any contaminant or fungal growth proved the efficacy of the protocol used.

\section{Identification of endophytic fungal isolates}

Fungal isolates thus recovered were identified on the basis of their morphological and reproductive characters observed microscopically, grown on PDA using standard identification manuals (14-16). The fungal isolates that failed to sporulate were categorized as mycelia sterilia and those having distinct morphological features were designated as morphotype. The isolated endophytic fungi were coded according to the site of collection as ZOJ ( $Z$. oxyphyllum from Jonai), ZOB (Z. oxyphyllum from Boko) and ZOG (Z. oxyphyllum from Goalpara).

\section{Fungal diversity data analysis}

Relative colonization frequency (CF \%) of endophytic species was calculated using the formula:

$\mathrm{CF} \%=\left(\mathrm{N}_{\text {col }} / \mathrm{N}_{\mathrm{t}}\right) \times 100$

Where, $\mathrm{N}_{\text {col }}$ stands for the number of segments colonized by each endophytic fungal species, and $\mathrm{N}_{t}$ stands for the total number of segments plated on media (17).

Dominant endophytic fungi recovered was calculated as percentage colony frequency divided by sum of percentage of colony frequency of all endophytes X 100 (18).

\section{Extraction of metabolites}

Pure endophytic fungal isolates were cultivated in Potato Dextrose Broth (PDB) in Erlenmeyer flasks containing $100 \mathrm{ml}$ of the medium each. Further, it was incubated in a BOD shaking incubator (Wosico WSW-132) at $28{ }^{\circ} \mathrm{C}$ for 2 weeks with a periodic 
shaking at $120 \mathrm{rpm}$. The fungal mycelia were filtered out through sterile Whatmann filter paper. Each of the liquid broth was then extracted with equal amount of ethyl acetate (EtOAc) using a separating funnel after vigorous shaking for 10-15 min. The supernatant was allowed to evaporate using a rotary evaporator (Wosico WSW-191) and the crude extracts were obtained. The crude extracts were then dissolved in $100 \%$ dimethyl sulphoxide (DMSO) and stored at $4{ }^{\circ} \mathrm{C}$ for determination of antimicrobial activity (19).

\section{Determination of antimicrobial activity}

Antimicrobial activities of the extracts were determined through agar well diffusion method $(20,21)$ against selected clinically important human pathogens. These included one gram +ve bacterium Staphylococcus aureus Rosenbach (MTCC 737); two gram -ve bacteria Pseudomonas aeruginosa (Schroeter) Migula (MTCC 424) and Escherichia coli (Migula) Castellani \& Chalmers (MTCC 443); and a fungal strain Candida albicans (Robin) Berkhout var. albicans (MTCC 227). The reference strains were procured from the Institute of Microbial Technology (IMTECH), Chandigarh, India. All the selected bacterial test pathogens as well as the fungal test pathogen were cultivated in liquid culture media i.e., on Nutrient Broth and Sabouraud Dextrose Broth respectively. Nutrient agar plates were then inoculated with $0.2 \mathrm{ml}$ of bacterial culture containing $1.0 \times 10^{6}$ cells. Likewise, Sabouraud Dextrose Agar plate was inoculated with $0.2 \mathrm{ml}$ of fungal culture containing $1.0 \times 10^{6}$ cells. They were evenly spread over respective plates using a sterile cotton swab and agar cups were prepared on them using a sterile cork borer $(7 \mathrm{~mm}$ in diameter). The agar cups were filled with $100 \mu \mathrm{l}$ of crude extract of each endophytic fungus and incubated at $37 \pm 1{ }^{\circ} \mathrm{C}$ for $24 \mathrm{hrs}$ and at $28 \pm 1{ }^{\circ} \mathrm{C}$ for $48 \mathrm{hrs}$ for bacterial and fungal pathogens respectively. The antimicrobial activity of the crude extracts was determined by measuring the clear zone of inhibition against the pathogenic organism around the agar cups. Dimethyl sulphoxide (DMSO) was used as negative control, whereas streptomycin sulphate $(10 \mu \mathrm{g})$ and Fluconazole $(25 \mu \mathrm{g})$ were used as positive control.

\section{Data analysis}

To evaluate the inhibitory effect of the extracts of endophytic fungi against the test pathogens, Dimensionality-reduction method, Principle Component Analysis (PCA) was used. Antimicrobial activity of the ethyl acetate extracts of the potent fungal isolates were analyzed against the four selected human test pathogens, namely, Staphylococcus aureus, Pseudomonas aeruginosa, Escherichia coli and Candida albicans. Correlation matrix in multivariate option was used to generate PCA biplots using PAST 4.02 PCA sofware $(22,23)$.

\section{Results}

\section{Isolation and identification of endophytic fungi from Zanthoxylum oxyphyllum}

Endophytic fungi were isolated from healthy leaves of Zanthoxylum oxyphyllum from three different sites of Assam in different media. Out of 150 leaf segments plated, a total number of 74 endophytic fungal isolates were recovered. The highest recovery of endophytes was obtained in PDA media (21.33\%), followed by PEA (10\%), MEA (9.33\%) and the least were in WA media (8.67\%). Maximum number of isolates were recovered from Boko (36), followed by Goalpara (25) and the least was from Jonai (13) (Table 1). The total colonizing frequency (CF\%) of endophytic fungi in healthy leaf tissues of $Z$. oxyphyllum was found to be $49.33 \%$ out of which isolates belonging to the genus Colletotrichum showed the highest colonization frequency (25.34\%), followed by non-sporulating isolates categorised as morphotypes of Mycelia sterilia (12.66\%) and the genus Curvularia (6.67\%) (Table 2). Other isolates include Fusarium oxysporum (2\%), Corynespora cassicola (2.70\%) and Aspergillus flavus (1.33\%) (Table 2) (Fig. 1). The commonly isolated species from all the sampling sites was found to be fungi belonging to the genera Colletotrichum. The second highest colonization frequency from all the sites was found to be that of non-sporulating fungi (Mycelia sterilia).

\section{Antimicrobial activity of endophytic fungi}

Endophytic isolates were screened for antimicrobial activity against four clinically important pathogenic human test organisms. The result showed that all of the fungal isolates displayed antimicrobial efficacy by inhibiting at least one of the test pathogens (Table 3). It was also observed that most of the isolates inhibited all the bacterial test pathogens considered. Amongst the isolates, crude extracts of six species of Colletotrichum showed considerable antimicrobial activity by inhibiting all the three bacterial pathogens and the pathogenic fungus with high zones of inhibition ranging from $20-25 \mathrm{~mm}$. Out of all the isolates, crude metabolites of Colletotrichum gloeosporioides showed the highest zones of inhibition against all the pathogens, followed by $C$. acutatum (Table 3). Metabolites of another isolate identified as Fusarium oxysporum showed very effective inhibition against all the four test pathogens (Fig. 2) (Table 3).

\section{Principle Component Analysis}

PCA biplot analysis of the extracts reveals the correlation of endophytic fungi against the pathogenic test microorganisms in terms of zones of inhibition observed (Fig. 3). The two principal components explained $82.58 \%$ of the total variance. Component 1 explained $51.48 \%$ of the variance, while the Component 2 explained $31.10 \%$ of the variance. It was observed that fungal isolates belonging to the genus Colletotrichum except $C$. dematium and $C$. acutatum showed positive and higher antagonistic activity against Staphylococcus aureus and Candida albicans. Similar result was also observed for Fusarium oxysporum. However, Colletotrichum siamense, $C$. gloeosporioides and $C$. boninense showed positive correlation indicating better antibacterial activity against $S$. aureus and Escherichia coli. Similarly, C. asianum, $C$. nymphae and F. oxysporum also showed positive correlation indicating more promising antimicrobial activity against $C$. albicans. However, a negative correlation was observed in the case of $C$. dematium and $C$. asianum as it showed 
Table 1. Endophytes recovered from Z. oxyphyllum leaf on different media from various sites.

\begin{tabular}{|c|c|c|c|c|c|c|}
\hline \multirow{2}{*}{ Sample } & \multirow{2}{*}{ Media* } & \multicolumn{3}{|c|}{ No. of colonies recovered from sites } & \multirow{2}{*}{$\begin{array}{l}\text { Total no. of fungal colonies recovered out } \\
\text { of } 150 \text { segments }\end{array}$} & \multirow{2}{*}{$\%$ of recovery } \\
\hline & & JO & BO & GO & & \\
\hline \multirow{5}{*}{ Leaf } & PDA & 4 & 13 & 15 & 32 & 21.33 \\
\hline & MEA & 2 & 9 & 3 & 14 & 9.33 \\
\hline & WA & 1 & 7 & 5 & 13 & 8.67 \\
\hline & $\begin{array}{l}\text { PEA } \\
\end{array}$ & 6 & 7 & 2 & 15 & 10.00 \\
\hline & Total isolates & 13 & 36 & 25 & 74 & \\
\hline
\end{tabular}

*PDA= Potato Dextrose Agar; MEA=Malt Extract Agar; WA=Water Agar ; PEA= Plant Extract Agar; JO= Jonai, BO=Boko, GO=Goalpara.

Table 2. Endophytic fungal composition in healthy leaf tissues of Z. oxyphyllum isolated from three sampling sites of Assam.

\begin{tabular}{|c|c|c|c|c|c|c|}
\hline \multirow{2}{*}{ Endophytic fungi } & \multicolumn{3}{|c|}{ Locations } & \multirow[t]{2}{*}{$\begin{array}{c}\text { Total isolates/150 } \\
\text { fragments }\end{array}$} & \multirow[t]{2}{*}{ CF (\%) } & \multirow[t]{2}{*}{$\begin{array}{c}\text { Frequency of dominant } \\
\text { endophytes (\%) }\end{array}$} \\
\hline & JO & BO & GO & & & \\
\hline Fusarium oxysporum & -- & 3 & -- & 3 & 2.00 & 4.05 \\
\hline Curvularia pallescens & -- & 3 & -- & 3 & 2.00 & 4.05 \\
\hline Curvularia protuberata & -- & -- & 4 & 4 & 2.67 & 5.41 \\
\hline Curvularia geniculata & -- & -- & 3 & 3 & 2.00 & 4.05 \\
\hline Aspergillus flavus & -- & 2 & -- & 2 & 1.33 & 2.70 \\
\hline Corynespora cassicola & 2 & -- & -- & 2 & 1.33 & 2.70 \\
\hline Colletotrichum dematium & 5 & -- & -- & 5 & 3.33 & 6.75 \\
\hline Colletotrichum siamense & -- & 6 & -- & 6 & 4.00 & 8.10 \\
\hline Colletotrichum gloeosporioides & -- & 7 & -- & 7 & 4.67 & 9.47 \\
\hline Colletotrichum acutatum & -- & 4 & -- & 4 & 2.67 & 5.41 \\
\hline Colletotrichum boninense & -- & -- & 7 & 7 & 4.67 & 9.47 \\
\hline Colletotrichum asianum & -- & -- & 4 & 4 & 2.67 & 5.41 \\
\hline Colletotrichum nymphae & -- & -- & 5 & 5 & 3.33 & 6.75 \\
\hline Morphotype sp.1 & 3 & -- & -- & 3 & 2.00 & 4.05 \\
\hline Morphotype sp.2 & 3 & -- & -- & 3 & 2.00 & 4.05 \\
\hline Morphotype sp.3 & -- & 5 & -- & 5 & 3.33 & 6.75 \\
\hline Morphotype sp.4 & -- & 6 & -- & 6 & 4.00 & 8.10 \\
\hline Morphotype sp.5 & -- & -- & 2 & 2 & 1.33 & 2.70 \\
\hline Total no. of isolates & 13 & 36 & 25 & 74 & 49.33 & 100 \\
\hline
\end{tabular}

$\mathrm{C} F=$ Colonization Frequency; JO=Jonai, $\mathrm{BO}=\mathrm{Boko}, \mathrm{GO}=$ Goalpara

higher antimicrobial activity against E. coli in comparison to the other three test pathogens. The PCA analysis also suggests that the isolates belonging to the genus Colletotrichum and the isolate $F$. oxysporum showed similar trends of antagonistic activity against the test pathogens by showing more inhibitory effect against $S$. aureus, C. albicans and $E$. coli (Fig. 3).

\section{Discussion}

Endophytic fungi are found to be distributed naturally within plants of both temperate and tropical regions around the world. In the present study, endophytic fungi harbouring healthy leaf tissues of $Z$. oxyphyllum, an ethnomedicinal plant of Assam, was investigated for their antimicrobial potential as there were no earlier reports of endophytic fungal associated to this plant. The result clearly indicated the occurrence of endophytic fungal community within the leaves of $Z$. oxyphyllum and 74 isolates belonging to 18 different species of endophytic fungi were isolated from 150 surface sterilized leaf fragments on different media. The highest percentage recovery of endophytes from the leaves of this plant was observed in PDA media. However, recovery of endophytic fungi was found to be merely similar in PEA and MEA media and the least recovery was observed from WA medium. Earlier reports on isolation of endophytic fungi have also indicated that PDA is the most suitable media for isolation of such fungi from medicinal plants and showed highest recovery of endophytes $(24,25)$. The maximum numbers of isolates were recovered from the samples collected from Boko and the least number of fungal colonies were isolated from the samples of Jonai. The variation and frequency of endophytic colonization among the sampling sites might be because of the environmental condition which corresponds with earlier reports on endophytic colonization (26). It has been reported that endophytic fungal communities vary according to time and space and is influenced by climatic and environmental conditions (27, 28). In this study, endophytic fungi belonging to different genera like Colletotrichum, Fusarium, Curvularia, Corynespora, Aspergillus and Mycelia sterilia were isolated from three different geographical sites of Assam. The genus Colletotrichum is isolated from all the three study sites considered for the study. This corresponds with earlier reports on colonization of endophytic fungi that suggest that the genus Colletotrichum is often isolated as dominant endophytic fungi from several medicinal plants species (29-31). 


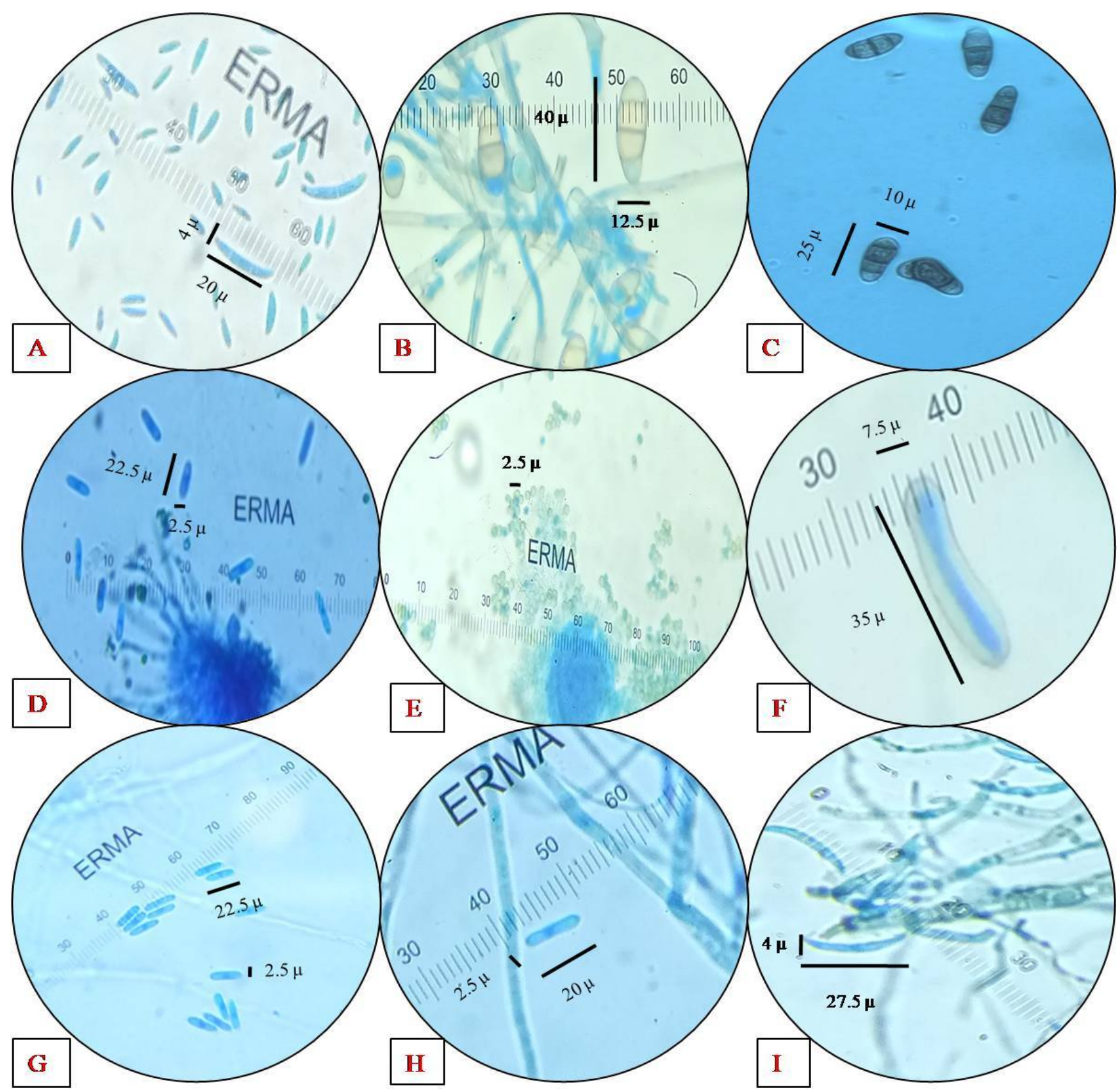

Fig. 1. Microscopic photographs of some isolated endophytic fungi- A) Fusarium oxysporum, B) Curvularia pallescens, C) Curvularia geniculata, D) Colletotrichum gloeosporoides, E) Aspergillus flavus, F) Corynespora cassicola, G) Colletotrichum siamense, H) Colletotrichum asianum, I) Colletotrichum dematium, (under 40x and 100x magnifications).

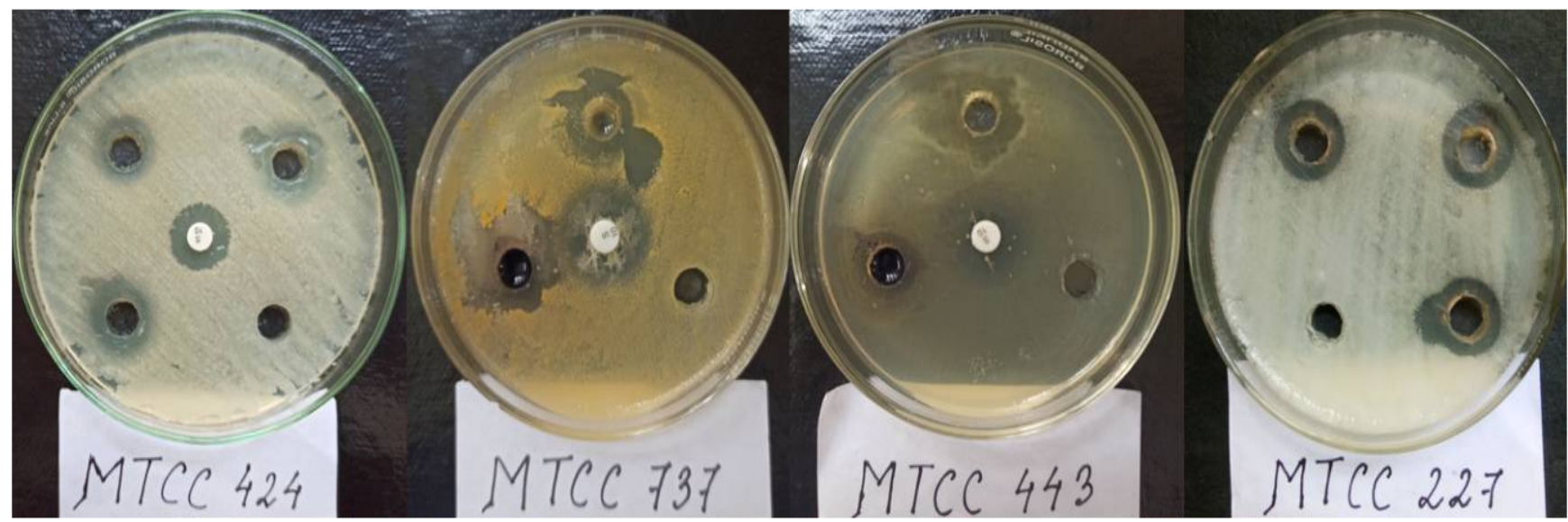

Fig. 2. Antimicrobial activity of the ethyl acetate extracts of some of the endophytic fungal isolates against selected test pathogens. (MTCC 424= P. aeruginosa; MTCC 737 $=$ S. aureus; MTCC $443=E$. coli; MTCC $227=$ C. albicans $)$. 
Table 3. Antimicrobial activity of endophytic fungal isolates of $Z$. oxyphyllum against pathogenic test organisms.

\begin{tabular}{|c|c|c|c|c|c|}
\hline \multirow{2}{*}{$\begin{array}{l}\text { Isolate } \\
\text { code }\end{array}$} & \multirow[b]{2}{*}{ Endophytic fungi } & \multicolumn{4}{|c|}{ Zone of inhibition(mm SD) } \\
\hline & & Candida albicans & Staphylococcus aureus & Escherichia coli & $\begin{array}{c}\text { Pseudomonas } \\
\text { aeruginosa }\end{array}$ \\
\hline ZOB2 & Fusarium oxysporum & $23.8 \pm 0.57$ & $23.5 \pm 1.00$ & $17.6 \pm 1.52$ & $17.0 \pm 1.00$ \\
\hline ZOB4 & Curvularia pallescens & $12.3 \pm 1.52$ & $11.3 \pm 1.52$ & $11.6 \pm 0.57$ & $13.6 \pm 0.57$ \\
\hline ZOG3 & Curvularia protuberata & $17.1 \pm 1.25$ & $12.1 \pm 1.04$ & $16.0 \pm 1.00$ & $11.1 \pm 0.76$ \\
\hline ZOG4 & Curvularia geniculata & $16.3 \pm 0.57$ & 0.00 & $12.5 \pm 1.80$ & 0.00 \\
\hline ZOB14 & Aspergillus flavus & $11.6 \pm 0.57$ & $13.6 \pm 0.57$ & $10.3 \pm 1.52$ & $11 \pm 1.00$ \\
\hline ZOJ2 & Corynespora cassicola & $12.6 \pm 1.52$ & 0.00 & 0.00 & $13.3 \pm 0.57$ \\
\hline ZOJ1 & Colletotrichum dematium & $14.4 \pm 0.37$ & $16.3 \pm 0.55$ & $18.2 \pm 0.55$ & $19.2 \pm 0.46$ \\
\hline ZOB3 & Colletotrichum gloeosporioides & $24.4 \pm 0.47$ & $24.7 \pm 0.60$ & $24.1 \pm 0.56$ & $23.8 \pm 1.04$ \\
\hline ZOB9 & Colletotrichum siamense & $23.7 \pm 0.46$ & $23.4 \pm 0.50$ & $23.2 \pm 0.50$ & $22.5 \pm 0.50$ \\
\hline ZOB21 & Colletotrichum acutatum & $24.2 \pm 0.45$ & $23.5 \pm 0.45$ & $24.5 \pm 0.50$ & $22.8 \pm 0.74$ \\
\hline ZOG1 & Colletotrichum boninense & $24.1 \pm 0.25$ & $24.4 \pm 1.00$ & $23.0 \pm 0.45$ & $18.9 \pm 0.90$ \\
\hline ZOG8 & Colletotrichum asianum & $23.2 \pm 0.04$ & $23.3 \pm 0.30$ & $22.4 \pm 0.37$ & $19.2 \pm 0.52$ \\
\hline ZOG11 & Colletotrichum nymphae & $24.2 \pm 0.17$ & $23.9 \pm 0.97$ & $22.0 \pm 0.60$ & $22.5 \pm 0.47$ \\
\hline ZOJ3 & Morphotype sp.1 & $12.0 \pm 1.00$ & $11.3 \pm 1.52$ & $17.6 \pm 0.57$ & 0.00 \\
\hline ZOJ4 & Morphotype sp.2 & $13.6 \pm 0.57$ & 0.00 & $12.5 \pm 0.76$ & 0.00 \\
\hline ZOB1 & Morphotype sp.3 & $12.4 \pm 1.28$ & $12.6 \pm 1.52$ & $11.4 \pm 0.57$ & $18.3 \pm 1.47$ \\
\hline ZOB7 & Morphotype sp.4 & $11.0 \pm 0.55$ & $17.2 \pm 0.58$ & $12.9 \pm 0.90$ & $13.5 \pm 0.92$ \\
\hline ZOG2 & Morphotype sp.5 & $18.2 \pm 0.34$ & $11.2 \pm 0.32$ & $17.3 \pm 0.47$ & $12.8 \pm 0.76$ \\
\hline
\end{tabular}

Values are mean of three replicates

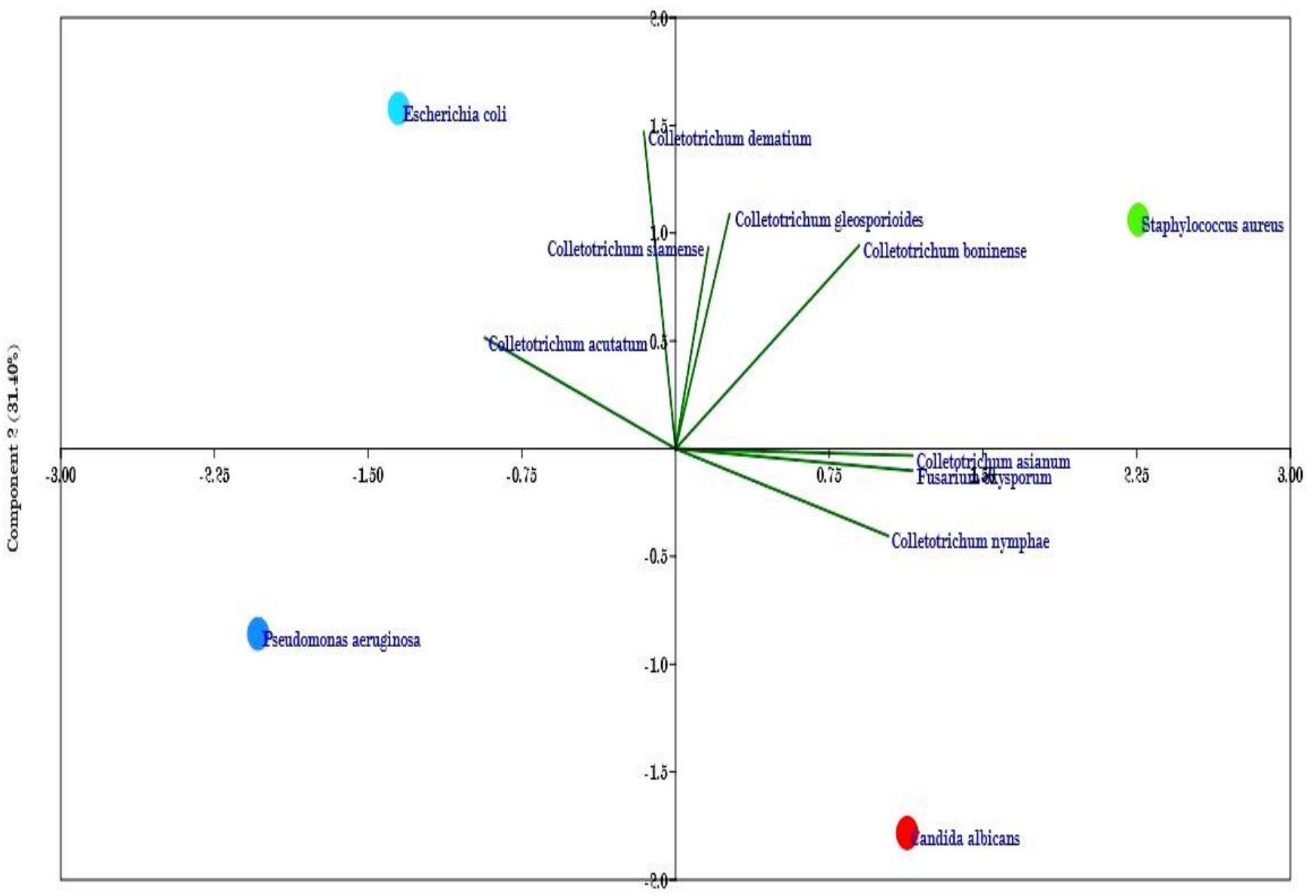

Component $1(51.48 \%)$

Fig. 3. Analysis of principal component of potent endophytic fungal species against human test pathogens.

In the present study, the crude metabolites of 14 out of the $18(77.78 \%)$ fungal strains showed prominent antimicrobial activity against at least one of all the test pathogens considered. The most potent isolate that effectively inhibited all the test pathogens was Colletotrichum gloeosporioides (ZOB3). This was followed by the $C$. siamense (ZOB9), $C$. boninense (ZOG1), C. acutatum (ZOB21), C. asianum (ZOG8) and 
C. nymphae (ZOG11). The crude extracts of the isolate identified as Fusarium oxysporum (ZOB2) also showed significant antimicrobial potential. However, all of the isolates showed significant antifungal activity. PCA analysis also clearly revealed the higher antimicrobial potential of the isolates belonging to the genus Colletotrichum as well as F. oxysporum. In many instances, endophytic fungi belonging to both of these genera have been reported to exhibit antimicrobial activity against a wide range of pathogens $(32,33)$. PCA biplot analysis also indicates a positive and higher efficiency of the isolates of genus Colletotrichum and F. oxysporum strain against mostly to Staphylococcus aureus and Candida albicans. Our results therefore clearly indicated that endophytic fungi obtained from leaves of $Z$. oxyphyllum have pharmaceutical potential as they produce antimicrobial compounds inhabiting the growth of pathogenic microorganisms. It can also be stated that the therapeutic properties of this plant could also be an outcome of endophytic colonization which produces biologically active compounds. Further evaluation of the bioactive of the strains obtained in this study would consequently aid towards the development of bioactive, pharmaceutically and commercially important antimicrobial compounds. Therefore, further studies towards this subject are now essential to identify the active compounds produced in order to discover novel drugs with antimicrobial activity.

\section{Conclusion}

The study revealed that Zanthoxylum oxyphyllum Edgew., a medicinal plant widely used by the local tribal communities of Assam, are colonized by endophytic fungi. The dominant endophytes were fungi belonging to genus Colletotrichum and Mycelia sterilia. The crude extracts obtained from the endophytic fungal isolate belonging to genus Colletotrichum and the species Fusarium oxysporum showed significant antimicrobial activity against all the selected clinically significant human test pathogens. Principal Component Analysis (PCA) indicated the crude extracts of the isolates belonging to Colletotrichum gloeosporoides, $C$. boninense and $C$. siamense showed positive and maximum inhibition against the $S$. aureus. Similarly, isolates $F$. oxysporum, $C$. asianum and $C$. nymphae showed positive and better antimicrobial potential against $C$. albicans. Further detailed investigation on the bioactive metabolites obtained from these endophytic fungal species would therefore lead to the discovery of efficient antimicrobial compounds with wide therapeutic applications.

\section{Acknowledgements}

The authors are thankful to the Department of Botany, Gauhati University, Assam, India as well as the Department of Biotechnology, Government of India, for providing all the necessary laboratory facilities and financial aid to carry out this particular research work.

\section{Authors' contributions}

RT carried out all the experiments. KT formatted the manuscript, designed, hypothesized the experiment and over all wrote the manuscript.

\section{Conflict of interests}

The authors announce no conflict of interests regarding the publication of this paper.

\section{References}

1. Vadhana P, Singh BR, Bharadwaj M, Singh SV. Emergence of herbal antimicrobial drug resistance in clinical bacterial isolates. Pharm Anal Acta. 2015;6:434. http://dx.doi.org/10.4172/2153-2435.1000434

2. Xing YM, Chen J, Cui JL, Chen XM, Guo SX. Antimicrobial activity and biodiversity of endophytic fungi in Dendrobium devonianum and Dendrobium thyrsiflorum from Vietnam. Curr Microbiol. 2011;62:1218-24. https://doi.org/10.1007/s00284-0109848-2

3. Zhao J, Shan T, Mou Y, Zhou L. Plant derived bioactive compounds produced by endophytic fungi. Mini Rev Med Chem. 2011;11:15968. http://dx.doi.org/10.2174/138955711794519492

4. Rodrigues RA, de Araujo AV, da Cunha RM, Carvalho CM. Antibacterial activity of endophytic fungi from the medicinal plant Uncariato mentosa (Willd.) DC. J Med Plant Res. 2018;12(15):179-85. https://doi.org/10.5897/JMPR2018.6558

5. Venieraki A, Dimou M, Katinakis P. Endophytic fungi residing in medicinal plants have the ability to produce the same or similar pharmacologically active secondary metabolites as their hosts. Hellenic Plant Protection Journal. 2017;10:51-66. http://dx.doi.org/10.1515/hppj-2017-0006

6. Deshmukh SK, Verekar SA, Bhave SV. Endophytic fungi: a reservoir of antibacterials. Front Microbiol. 2014;5:715. https:// doi.org/10.3389/fmicb.2014.00715

7. Strobel GA, Daisy B. Bioprospecting for microbial endophytes and their natural products. Microbiol Mol Biol Rev. 2003;67:491-502. https://doi.org/10.1128/mmbr.67.4.491502.2003

8. Kusari S, Pandey SP, Spitellera M. Untapped mutualistic paradigms linking host plant and endophytic fungal production of similar bioactive secondary metabolites. Phytochem.2013;91:8187. https://doi.org/10.1016/j.phytochem.2012.07.021

9. Buragohain J, Konwar BK, Bordoloi MJ. Isolation of an antimicrobial compounds from the tender shoots of Zanthoxylum. Der Pharmacia Sinicia. 2011;2(6):149.

10. Medhi K, Purohit BP, Gogoi AJ, Saikia SP, Kanjilal PB, Bhau BS. Molecular marker based genetic diversity analysis of two economically important plants (Zanthoxylum hamiltonianum and Nepenthes khasiana) of North-East India. Biodiversity in herbal medicine. New Delhi: IQAC Synod College and Akansha Publishing House; 2009. p. 47-55.

11. Zhao J, Zhou L, Wang J, Shan T, Lingyun Z, Liu X, Gao L. Endophytic fungi for producing bioactive compounds originally from their host plants. In: Mendez-Vilas A editor. Current Research, Technology and Education Topics in Applied Microbiology and Microbial Biotechnology. 2010;(1):567-76.

12. Stierle A, Strobel G, Sierle D. Taxol and taxane production by Taxomyces andreanae, an endophytic fungus of Pacific yew. Science.

https://doi.org/10.1126/science.8097061 1993;260(5105):214-16

13. Schulz B, Guske S, Dammann U, Boyle C. Endophyte-host interactions. II. Defining symbiosis of the endophyte-host interaction. Symbiosis. 1998;25:213-27.

14. Barnett HL, Hunter BB. Illustrated Genera of Imperfect Fungi. $4^{\text {th }}$ ed. St. Paul Minnesota (USA):APS Press, 1996. 
15. Damm U, Johnston PR, Weir BS. The Colletotrichum gloeosporioides species complex. Stud Mycol. 2012;73:115-80. https://doi.org/10.3114/sim0011

16. Gilman JC. A Manual of Soil Fungi. $2^{\text {nd }}$ ed. Iowa (USA):Iowa State College Press, 1971.

17. Hata K, Futai K. Endophytic fungi associated with healthy pine needles and needles infested by the pine needle gall midge, Thecodiplosis japonensis. Can J Bot. 1995;73:384-90. https://doi.org/10.1139/b95-040

18. Tayung K, Jha DK. Antimicrobial evaluation of some fungal endophytes isolated from bark of Himalayan yew. World J Agric Sci. 2006;2:489-94.

19. Padhi S, Tayung K. Antimicrobial activity and molecular characterization of an endophytic fungus, Quambalaria sp. isolated from Ipomoea carnea. Ann Microbiol. 2013;63:793800. https://doi.org/10.1007/s13213-012-0534-4

20. Magaldi S, Mata-Essayag S, Hartung de Capriles C, Perez C, Collela MT, Olaizola C, et al. Well diffusion for antifungal susceptibility testing. Int J Infect Dis. 2004;8(1):39-45. http://dx.doi.org/10.1016/j.ijid.2003.03.002

21. Valgas C, De Souza SM, Smânia EFA, Jr AS. Screening methods to determine antibacterial activity of natural products. Braz Microbiol. 2007;38:369-80. https://doi.org/10.1590/S151783822007000200034

22. Hammer $\emptyset$, Harper DAT, Ryan DP. PAST: paleontological statistics software package for education and data analysis. Palaeontol Electron. 2001;4(1):1-9.

23. Alvin A, Miller KI, Neilan BA. Exploring the potential of endophytes from medicinal plants as sources of antimycobacterial compounds. Microbiol Res. 2014;169(78):483-95. https://doi.org/10.1016/j.micres.2013.12.009

24. Sia EdF, Marcon J, Luvizotto DM, Quecine MC, Tsui S, Pereira JO, et al. Endophytic fungi from the Amazonian plant Paullinia cupana and from Olea europaea isolated using cassava as an alternative starch media source. Springerplus. 2013;2:579. https://doi.org/10.1186/2193-1801-2-579
25. Rodrigues RA, de Araujo AV, da Cunha RM, Carvalho CM. Antibacterial activity of endophytic fungi from the medicinal plant Uncariato mentosa (Willd.) DC. J Med Plant Res. 2018;12(15):179-85. https://doi.org/10.5897/JMPR2018.6558

26. Nair DN, Padmavathy S. Impact of endophytic microorganisms on plants, environment and humans. Sci World J. 2014; (2):250693. https://doi.org/10.1155/2014/250693

27. Fisher PJ, Petrini O, Petrini LE, Sutton BC. Fungal endophytes from the leaves and twigs of Quercus ilex L. from England Majorca and Switzerland. New Phytol. 1994;127:133-37. https:// doi.org/10.1111/j.1469-8137.1994.tb04267.x

28. Gao XX, Zhou H, Xu DY, Yu CH, Chen YQ, Qu LH. High diversity of endophytic fungi from the pharmaceutical plant, Heterosmilax japonica Kunth revealed by cultivationindependent approach. FEMS Microbiol Lett. 2005;249:255-66. https://doi.org/10.1016/j.femsle.2005.06.017

29. Siqueira VM, Conti R, Araujo JM, Souza-Motta CM. Endophytic fungi from the medicinal plant Lippia sidoides Cham. and their antimicrobial activity. Symbiosis. 2011;53:89-95. https://doi.org/ 10.1007/s13199-011-0113-7

30. Thalavaipandian A. Diversity of fungal endophytes in medicinal plants of Courtallam hills, Western Ghats, India. Mycosphere. 2011;2:575-82. https://doi.org/10.5943/mycosphere/2/5/7

31. Strobel G, Daisy B, Castillo U, Harper J. Natural products from endophytic microorganisms. J Nat Prod. 2004;67(2):257-68. https://doi.org/10.1021/np030397v

32. Talukdar R, Wary S, Mili C, Roy S, Tayung K. Antimicrobial secondary metabolites obtained from endophytic fung inhabiting healthy leaf tissues of Houttuynia cordata Thunb., an ethnomedicinal plant of Northeast India. I Appl Pharm Sci. 2020;10(09):99-106. https://doi.org/10.7324/JAPS.2020.10912

33. Barik BP, Tayung K, Jagadev PN, Dutta SK. Phylogenetic placement of an endophytic fungus Fusarium oxysporum isolated from Acorus calamus rhizomes with antimicrobial activity. EJBS. 2010;2(1):8-16. 